\title{
USE OF AIRBORNE $\gamma$-RAY SPECTROMETRY FOR ENVIRONMENTAL ASSESSMENT OF THE REHABILITATED NABARLEK URANIUM MINE, AUSTRALIA
}

\author{
PAUL MARTIN ${ }^{1,2, *}$, STEPHEN TIMS $^{1,3}$, ANTHONY MCGILL $^{4}$, BRUCE RYAN $^{1}$ \\ and KIRRILLY PFITZNER ${ }^{1}$ \\ ${ }^{1}$ Environmental Research Institute of the Supervising Scientist (eriss), Darwin, NT, Australia; \\ ${ }^{2}$ Agency's Laboratories Seibersdorf, International Atomic Energy Agency, Vienna, Austria; \\ ${ }^{3}$ Department of Nuclear Physics, Australian National University, Canberra, ACT, Australia; \\ ${ }^{4}$ Northern Territory Department of Business, Industry \& Resource Development, Darwin, \\ NT, Australia \\ (*author for correspondence,e-mail: p.martin@iaea.org)
}

(Received 16 May 2004; accepted 12 May 2005)

\begin{abstract}
This article describes an airborne $\gamma$ survey of a $7 \times 5 \mathrm{~km}$ region around the rehabilitated Nabarlek uranium mine in northern Australia. An unusually tight line spacing (100 m) and low aircraft height $(50 \mathrm{~m})$ were used, enabling the survey to distinguish man-made structures such as ponds and accommodation areas, as well as creek lines. Positive correlations between airborne data and groundbased readings enabled an estimation of the average absorbed dose rate arising from terrestrial $\gamma$ radiation over large areas of the site to be derived. For the fenced minesite area this estimate was 0.31 $\mu \mathrm{Gy} \mathrm{hr}^{-1}$. The airborne survey data were found to be invaluable in helping to plan further ground-level investigations and showed promise as an assessment tool for rehabilitated minesites.
\end{abstract}

Keywords: airborne gamma survey, dose rate estimation, Nabarlek, radiological assessment, rehabilitation, uranium mining

\section{Introduction}

Airborne $\gamma$ radiometric surveys have been used extensively over several decades for mineral exploration and geological mapping purposes (Galbraith and Saunders, 1983; Smith, 1985; Zhang et al., 1998). In recent times, increasing attention has been paid to the effect of geochemistry and geomorphology on the signal, and hence the use of the technique for soil mapping and for land management applications (Cook et al., 1996; Dickson and Scott, 1997; Wilford et al., 1997; Pickup and Marks, 2000).

By contrast, only a few studies have been published on their use for detection of environmental contamination. Moreover, these have generally been concerned with determining the extent of contamination following nuclear accidents or for locating strong artificial sources (IAEA, 1991; Lepel et al., 1998).

There have been few reported cases of airborne $\gamma$ radiometric surveys being used in mining impact studies (an exception is the study of Winkelmann et al., 2001). 
Wherever the K-U-Th signature of mine waste materials differs from that of soils in the vicinity, there is potential to use $\gamma$ radiometric surveys for such purposes as delineating the extent of contaminated areas, monitoring of erosional processes and checking for the adequacy of rehabilitation. Many mineral orebodies, and/or the rock systems containing them, have elevated radionuclide activity concentrations (Plant and Saunders, 1996; Dickson and Scott, 1997; Kleinschmidt, 1998), and hence so do also mine/mill materials such as tailings and waste rock.

In this paper, an airborne $\gamma$ radiometric survey of an area covering the former Nabarlek uranium minesite in northern Australia is described. This survey is part of a long-term study of Nabarlek which aims to provide a comprehensive database of the environmental and, in particular, radiological conditions of the site. The airborne $\gamma$ survey was commissioned in order to provide a geographic dataset which could be used in planning detailed ground-based studies. In addition, it provides a useful test case of the application of the technique to radiological impact assessment of uranium mining operations.

\section{Site Description}

The Nabarlek mine was located in the headwaters of Cooper Creek, a tributary of the East Alligator River in the Northern Territory of Australia. The area is located within the Arnhem Land Aboriginal reserve. The climate is tropical monsoonal, with contrasting wet (approximately November to April) and dry (approximately May to October) seasons.

The geology of Nabarlek is dominated by the Pine Creek Geosyncline which stretches from south west of Pine Creek to north east of Nabarlek and covers the majority of the Alligator Rivers region. This geological structure consists of a broad belt of regionally deformed Lower Proterozoic metasediments overlaying an Archaean aged basement. The metasediments were deposited under predominately shallow marine conditions in an intracratonic basin and were metamorphosed and intensely folded during an orogenic episode. Further subsidence of the Geosyncline at 1800 My resulted in deformation and metamorphism of the Lower Proterozoic sediments particularly in the north-east (Needham and Stuart-Smith, 1976). The 200-400 m thick Arnhem Land Plateau overlays the eastern part of the Pine Creek Geosyncline and is comprised of Middle Proterozoic coarse grained sandstones and minor conglomerates with interbedded basalt flows (Needham, 1988). This rock unit is known as the Kombolgie Formation and displays a marked unconformity with the Lower Proterozoic rocks below (Uren, 1992).

The Nabarlek uranium mineralisations are hosted in the Myra Falls Metamorphics (Needham, 1988) which may not have coincided, but are associated with the metamorphosed and metasomatosed sediments in the North eastern area of the Geosyncline. The Myra Falls Metamorphics are thought to correlate with the lower 
members of the Cahill Formation (Battey et al., 1987) and are metamorphically differentiated schist and gneiss rocks comprising of banded feldspar-mica-quartz gneiss and schist \pm amphibole and garnet.

The near-surface uranium mineralisation was discovered by Queensland Mines (subsidiary of Pioneer International Limited) in June 1970. The Nabarlek ore body was situated within a heavily chloritised deformation zone with the uranium mineralization contained in massive fine-grained dark green replacive chlorite rock, together with sericite and hematite, transgressive to schistosity. Sulfide minerals were in only minor amounts, occurring mainly as disseminations within the ore body (Anthony, 1975).

The ore body was approximately $230 \mathrm{~m}$ long with an average true thickness of $10 \mathrm{~m}$. The mineralisation extended from the surface to a depth of about $85 \mathrm{~m}$ (Anthony, 1975). Most of the ore was at a depth less than $45 \mathrm{~m}$ (Battey et al., 1987). The grade variation within the ore body was extreme ranging from 0.1 to $72 \% \mathrm{U}_{3} \mathrm{O}_{8}$ (Battey et al., 1987).

Queensland Mines Ltd (QML) mined out the Nabarlek orebody in just over 4 months of the dry season of 1979. 600,000 tonnes of average $2 \%$ grade ore were stockpiled and subsequently milled and the uranium oxide sold from 1980 to 1988. This mining/stockpiling/milling sequence was made possible by the small size of the high-grade orebody.

Rock types in the immediate vicinity of the ore body were chlorite-, muscovite, and sericite-rich schist, and below the ore body, at a vertical depth of $470 \mathrm{~m}$, the metasediments were intruded by the Nabarlek Granite (Battey et al., 1987). Schistose material from the waste rock dump was used as soil medium during rehabilitation (Waggitt and Woods, 1998) and the overall land surface of the mine was covered with run-of-mine waste rock (Waggitt, 2001). The waste rock is composed of quartz-mica, chlorite-mica and quartz-chlorite schist which weathers very quickly to form clay, fine gravels and micaceous sands. Major rehabilitation and decommissioning works were completed at the end of 1995.

Figure 1 shows the layout of operations and the water management system at Nabarlek. The stockpile runoff pond (SPROP) was the main water storage for the plant (mill) operation. The sequential mining/milling method meant that tailings could be placed directly into the mine pit, obviating the need for a separate aboveground tailings dam. Milling was by an acid leach process, with tailings being neutralised by lime before deposition in the pit. Water was decanted back from the pit, treated with barium chloride (to reduce ${ }^{226} \mathrm{Ra}$ concentrations by co-precipitation with barium sulfate) and pumped to evaporation pond 2 (EP2). Evaporation pond 1 (EP1) acted as an emergency receptacle for tailings and pit water. Runoff from the plant area was retained in the plant runoff pond. Between 1984 and 1987 spray irrigation ("land application") was used over the "airstrip LAA" and "forest LAA" areas to dispose of excess water.

On mine establishment, removed topsoil was stored in heaps to the west of EP2 or, in the case of the pit topsoil, to the east of the pit. On rehabilitation, this soil was 


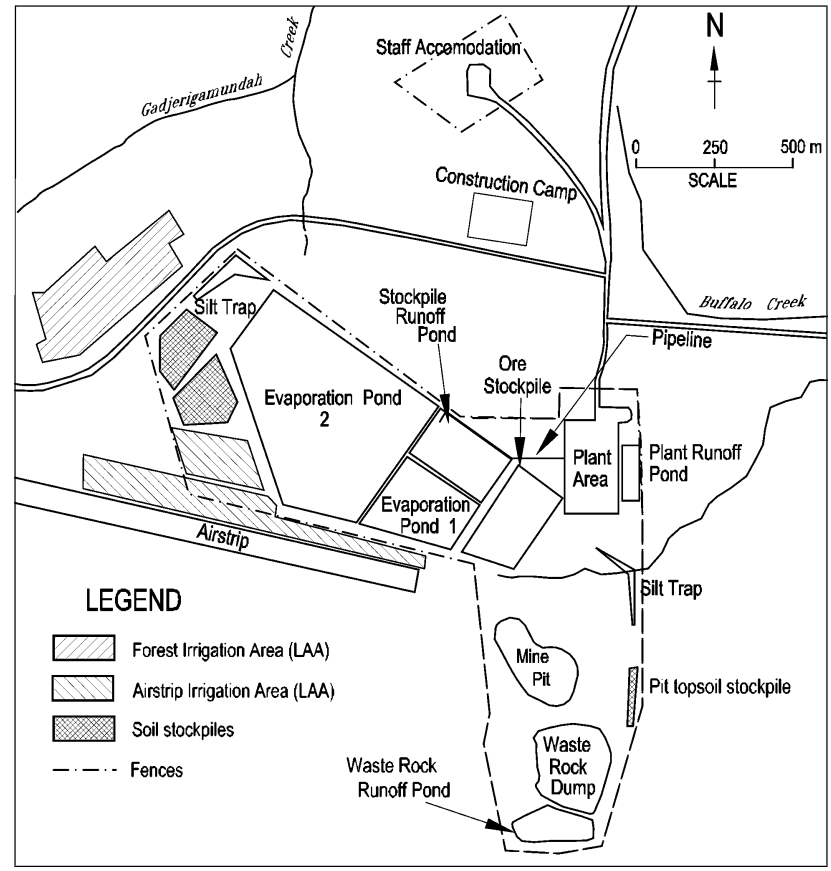

Figure 1. Layout of operations at the Nabarlek uranium mine.

used as fill rather than as a surface cover, as waste rock material was believed to be a better substrate for tree growth and likely to cause less problems with invasive weeds.

During construction, the workers lived at a camp about $1 \mathrm{~km}$ north of the pit area. More substantial worker accommodation was then built at a site just north of this camp. The nearest site of public occupation during operations was the Aboriginal camp at Mankinkinkani (Figure 2). This camp has been abandoned, and the nearest populated areas are now the Aboriginal camp of Mandilbarreng ( $23 \mathrm{~km}$ east-northeast) and the township of Gunbalanya (30 km west). In addition, the Waidaboonar Aboriginal camp (55 km north-west) is located near the Cooper Creek, downstream of Nabarlek.

\section{Methods}

The airborne survey was flown by a World Geoscience Corporation aircraft on 19th July 1997 (Figure 2). In the Cooper Creek only the western channel had flowing water, to a maximum depth of about $0.2 \mathrm{~m}$. Also under water was a small area $(45 \times 20 \mathrm{~m})$ in the south-east corner of the former plant runoff pond.

Surveys for mineral exploration commonly use line spacings of a few hundred meters. However, this is unlikely to be adequate for minesite assessment purposes, 


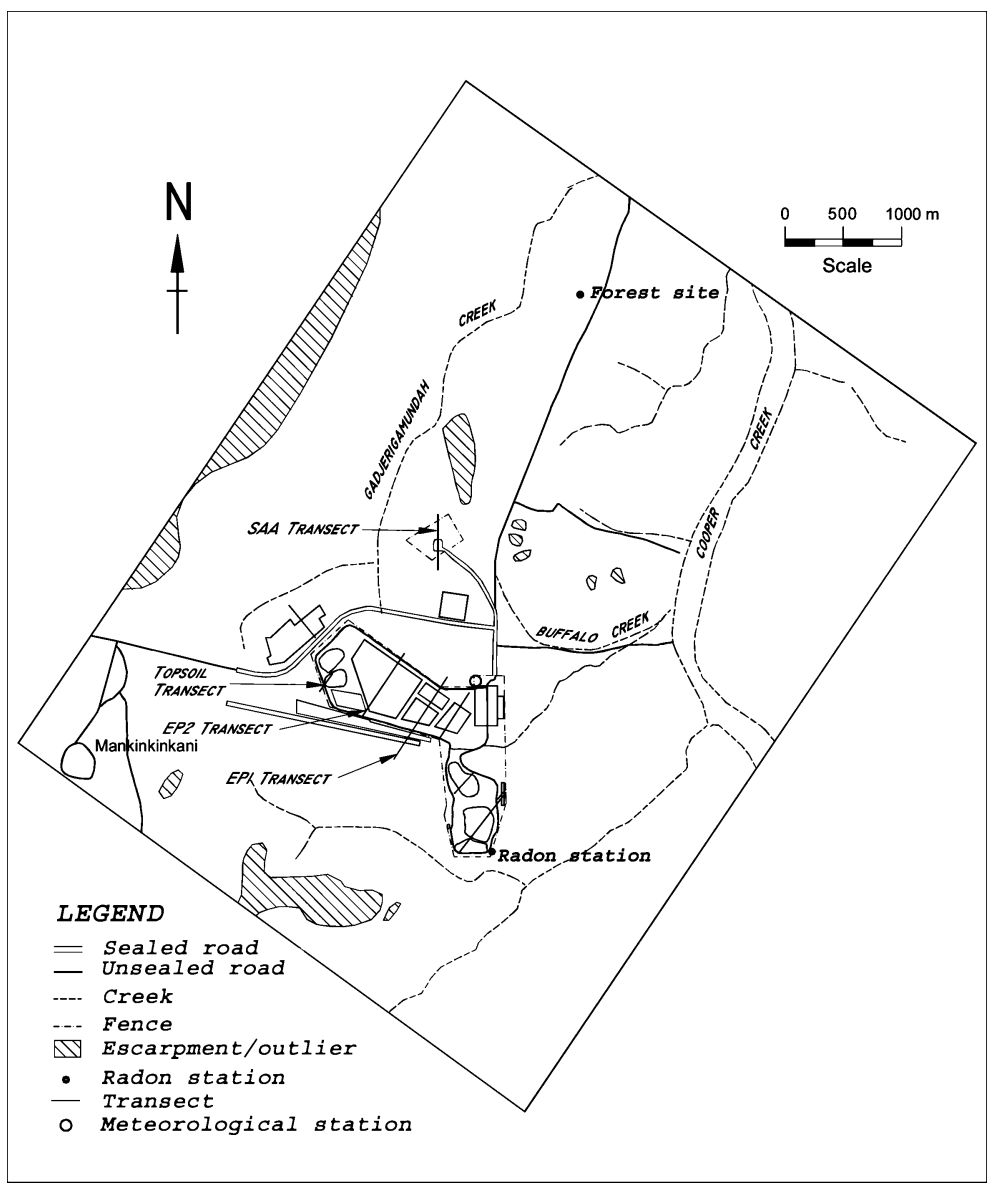

Figure 2. Extent of the airborne radiometric survey and location of transects.

where the small size (of the order of a few hundreds of meters down to a few tens of meters or even less) of the features of interest needs to be taken into account. For the present survey, seventy lines in an approximately north-west/south-east orientation were flown with a nominal line spacing of $100 \mathrm{~m}$, a mean terrain clearance of $50 \mathrm{~m}$ and a ground speed of $\sim 60 \mathrm{~m} \mathrm{~s}^{-1}$. Six tielines (south-west/north-east) were flown at a line spacing of $1000 \mathrm{~m}$, giving a rectangular area flown of approximately $7 \mathrm{~km} \times 5$ $\mathrm{km}$. Deviations from the nominal flight lines were generally not more than $\sim 20-30$ $\mathrm{m}$. Terrain clearance was mainly in the range of $40-60 \mathrm{~m}$, but was as low as $20 \mathrm{~m}$ above some rocky outliers/pillars, and as high as $90 \mathrm{~m}$ to either side of such outliers. A NaI(Tl) detector pack with a total crystal volume of 33.56 litres was used.

Spectral reduction and gridding were carried out by World Geoscience Corporation. Their spectral analysis software applies a fitting routine to the 256-channel spectrum, rather than using the conventional window processing method. Following processing, the net count rate data were supplied as a raster dataset. 
Current industry practice for airborne radiometric survey data reduction does not include provision of an error estimate. The results presented in this paper are in the units of counts $\mathrm{s}^{-1}$. Since the counting period was $1 \mathrm{~s}$, an indication of the expected counting statistic error (1 standard deviation) could be obtained from the square root of the given count rate, but it must be borne in mind that this is only an approximation, and will generally represent a minimum value. This is because the data are net count rates, and are the result of proprietary routines which include spectrum fitting, allowance for variables such as aircraft height, and gridding (including interpolation) to produce a smoothed geographic dataset.

Spectral analysis of gamma ray surveys using $\mathrm{NaI}(\mathrm{Tl})$ detectors normally gives three bands of information. Potassium- 40 is obtained from the peak at $1.46 \mathrm{MeV}$. Bands eU ("uranium equivalent") and eTh ("thorium equivalent") represent the main peaks used for measurement of U- and Th-series activity respectively. Although often referred to as the "uranium" and "thorium" peaks, these are essentially associated with $\gamma$-rays which arise in the decay of ${ }^{214} \mathrm{Bi}(1.73$ and $1.76 \mathrm{MeV})$ and ${ }^{208} \mathrm{Tl}(2.62 \mathrm{MeV})$.

The common use of the terms "uranium" and "thorium" for the two peaks at 1.73-1.76 MeV and 2.62 MeV implies an assumption that the $U$ and Th series can be considered in secular equilibrium for the purposes of interpretation of field $\gamma$ spectrometry data. Although this will generally hold for the Th series in "natural" landscapes (Dickson and Scott, 1997), it is less reliable in environmental impact investigations, where recent human activities may have led to element separations. An assumption of secular equilibrium for the $U$ series is unfounded even for natural landscapes. Contributions to the eU signal can be predominantly attributed to two sources: ${ }^{222} \mathrm{Rn}$ in the ground (which should be close to equilibrium with its parent ${ }^{226} \mathrm{Ra}$ ) and ${ }^{222} \mathrm{Rn}$ in the air.

Measurements of ${ }^{222} \mathrm{Rn}$ concentrations in air were made on the day of the flight at two locations: a permanent $\mathrm{Rn}$ station located to the south-east of the waste rock dump area ("Rn station site", Figure 2), and a temporary station set up to the north-east of Nabarlek ("Forest site"). Both instruments measure Rn by detection of the alpha decay of its progeny using a $\mathrm{ZnS}$ scintillator/photomultiplier system.

All ground-based $\gamma$ measurements were performed in the mid- to late-dry seasons (June to August) of 1997 and 1998. At this time of year, surface soil moisture contents for the region are very low (typically less than 2\%). Even surface soils on creek bed sites were very dry, with the exception of points where there was flowing water. Measurements were made with a portable $3^{\prime \prime} \times 3^{\prime \prime} \mathrm{NaI}(\mathrm{Tl}) \gamma$ spectrometer (Geofyzika GS-256), positioned $1 \mathrm{~m}$ above the ground. This detector has internal spectrum stabilisation using a ${ }^{137} \mathrm{Cs}$ reference source and collects 256 channel $\gamma$ data over the energy range $E_{\gamma}=0-3000 \mathrm{keV}$. Count periods ranging from 100 to $800 \mathrm{~s}$ duration were used. The 3-window processing technique was used, giving results for " $40 \mathrm{~K}$ ", "eU" and "eTh". Calibration constants determined by the manufacturer using standard test pads were used to convert count rates to nominal activity concentrations for these three elements. At each measurement site a recording of 
the $\gamma$ dose rate was also made for comparative purposes. To this end high-sensitivity compensated Geiger Müller tubes (Mini Instruments type 6-80 with MC-70 tubes) were mounted $1 \mathrm{~m}$ above the ground, and the total counts recorded over each of three periods of 100-300 s duration. The tubes have calibrations based on $\gamma$-rays arising from the decay of ${ }^{226} \mathrm{Ra}$ and its progeny, and consequently are well suited to dose assessment at uranium minesites.

The majority of ground-based readings were made at regular distances along transects across features of interest. Readings were usually spaced $30 \mathrm{~m}$ apart, but intervals of $15 \mathrm{~m}$ were used on the topsoil site. Transects were used primarily because they allowed a ready comparison with the results of the airborne survey. Figure 2 shows the location of the transects performed. The plant/offices and plant runoff pond areas were exceptions to this approach, with ground-based readings being made at predetermined random locations within each of a number of grids covering these two areas $(50 \times 50 \mathrm{~m}$ grids for the plant/offices and $25 \times 25 \mathrm{~m}$ for the plant runoff pond).

\section{Airborne Survey}

As discussed above, the eU signal includes a contribution from ${ }^{222} \mathrm{Rn}$ in the air. Radon-222 concentrations in air can vary significantly over the course of a day as a result of changes in the stability of the atmospheric conditions. This can lead to striping in the $\mathrm{eU}$ data for airborne surveys, i.e. the data for flight lines captured during periods of high ${ }^{222} \mathrm{Rn}$ concentration can lead to stripes of higher eU count rate running across the image (Clifton, 1989; Minty et al., 1997). During July the ${ }^{222} \mathrm{Rn}$ concentration at Nabarlek typically drops by more than an order of magnitude in the mornings (Martin et al., 2004), with decreases from over $500 \mathrm{~Bq} \mathrm{~m}^{-3}$ to $<10$ $\mathrm{Bq} \mathrm{m}^{-3}$ over the course of a few hours being common (Bollhöfer et al., 2004).

During the present survey, ${ }^{222} \mathrm{Rn}$ concentration measurements were made in air at $1.5 \mathrm{~m}$ height at the Rn station and Forest sites on the day of the flight, as well as wind speed at $10 \mathrm{~m}$ height at a meteorological station close to the former plant/offices area (Figure 2; Bollhöfer et al., 2004). Although half-hourly average wind speeds were not particularly high over the period (about 1 to $1.6 \mathrm{~m} \mathrm{~s}^{-1}, \mathrm{NE}$ ), ground observations showed that conditions were quite gusty at times. Radon-222 concentrations were low $\left(5-10 \mathrm{~Bq} \mathrm{~m}^{-3}\right)$ and steady at both sites for the entire duration of the flight (1100 to $1520 \mathrm{~h}$ ), presumably reflecting the unstable atmospheric conditions. In this respect, conditions were ideal for collection of eU data.

Processed airborne gamma spectrometry data can be presented in a variety of ways to enhance interpretation. Commonly, the gridded data are displayed directly on a computer monitor by mapping the count rate values into a set of either brightness levels or colours for each pixel. There are several ways in which the range of readings for a radioelement can be mapped, with the optimal method depending on the application. For rehabilitated minesite applications, it is often the anomalously high pixel values that are of importance. In this case, a mapping method can be 
used which emphasizes these higher count rate readings, and is the approach used here. However, use of this method means that the higher count rate regions are emphasized at the expense of loss of information for lower count rate regions.

Figures 3-5 show the results obtained for $\mathrm{eU},{ }^{40} \mathrm{~K}$ and eTh count rate as gridded colour images, with colours being assigned to various data ranges. Because the eU and ${ }^{40} \mathrm{~K}$ data were positively skewed, and the higher count rates were of interest, the data values were grouped using equal intervals at $10 \%$ of the count rate range. For example, the maximum count rate for eU was 426 counts $\mathrm{s}^{-1}$. The red colour (Figure 3) indicates the area where $90-100 \%$ of the maximum count was recorded (i.e. $384-426$ counts s $^{-1}$ ). The $0-10 \%$ of the eU data range accounted for over $90 \%$ of the cumulative percent. In the cases of eU and ${ }^{40} \mathrm{~K}$, pixels have been coloured after grouping count rates into nine classes (greater than $10 \%$ count rates). In the case of eTh, only five classes (counts greater than $50 \%$ of the maximum) have been used because of the much smaller range in count rate.

As expected, there is a strong eU signal above the former Nabarlek mine area. The locations of the waste rock dump, mine pit area and evaporation ponds area are quite apparent in the eU signal. A blue/green area to the north-east of the pit marks the location of the former plant runoff pond. This pond was only $180 \mathrm{~m} \times 60 \mathrm{~m}$ in size, and yet its location and N/S orientation are easily seen from the airborne survey data. On rehabilitation the pond was covered with waste rock from beneath

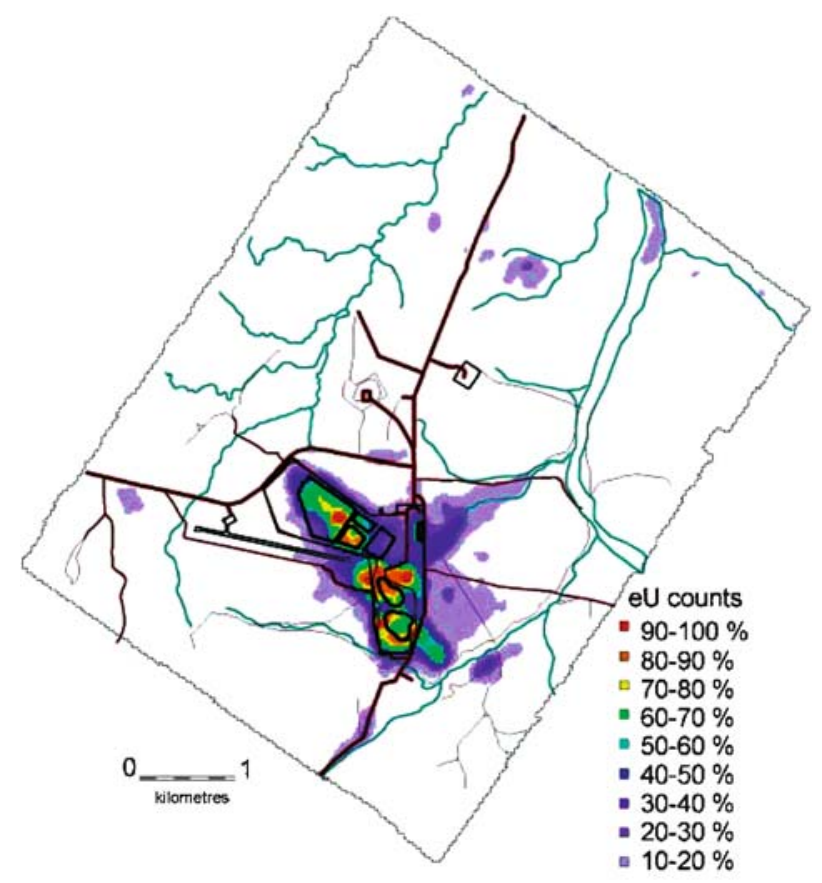

Figure 3. Airborne eU signal as a coloured image. 


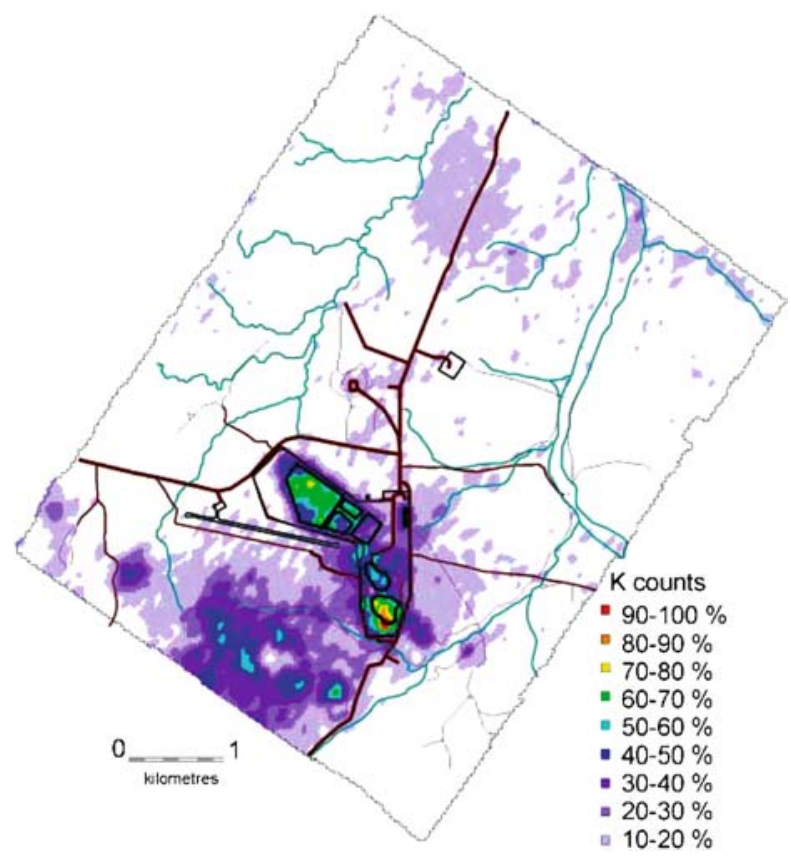

Figure 4. Airborne ${ }^{40} \mathrm{~K}$ signal as a coloured image.

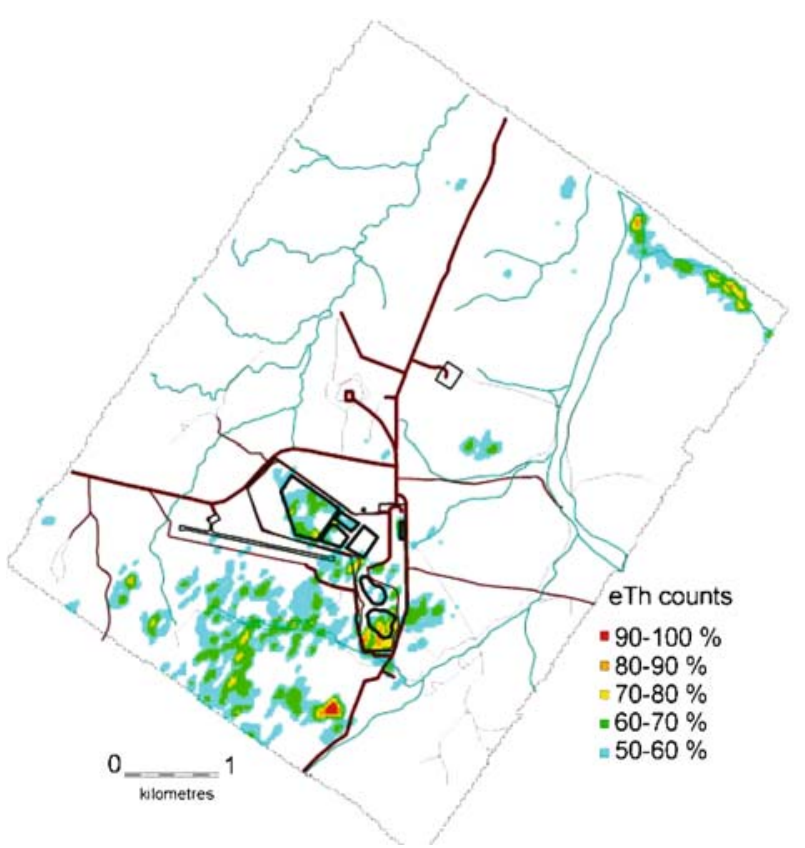

Figure 5. Airborne eTh signal as a coloured image. 
TABLE I

Correlation matrix for the airborne survey dataset

\begin{tabular}{llll}
\hline & ${ }^{40} \mathrm{~K}$ & $\mathrm{eU}$ & $\mathrm{eTh}$ \\
\hline${ }^{40} \mathrm{~K}$ & 1.000 & 0.726 & 0.698 \\
$\mathrm{eU}$ & & 1.000 & 0.421 \\
$\mathrm{eTh}$ & & & 1.000 \\
\hline
\end{tabular}

the former ore stockpile area. Most of the mine-related features visible on the eU image may also be seen clearly on the ${ }^{40} \mathrm{~K}$ image. Even on the eTh image, the location and shape of the evaporation ponds and waste rock dump areas are visible. Table I shows that for the dataset as a whole, there are positive correlations between the eU, ${ }^{40} \mathrm{~K}$ and eTh count rate data.

Leading away from the waste rock dump/pit area towards the north-east may be seen a line of elevated eU activity. Higher activity areas may also be seen to the east and south-east of the waste rock dump/pit area. At first sight these features seem to indicate erosion of material from the minesite, especially since the line to the north-east is correlated with a southern arm of the Buffalo Creek. However, diagrams of "surface radiometry", "Rn in soil" and "U geochemistry" from the original environmental impact statement (QML, 1979) show that similar features were present prior to mining operations. This is not surprising, since the Nabarlek 1 orebody outcropped at the surface, and so natural pre-mining erosion would be expected to have resulted in elevated eU activity downstream. Visual observation of a channel along the Buffalo Creek line showed the presence of some apparently mine-related material, and more detailed ground-based investigations are presently underway to study erosion and deposition in this system.

An interesting feature of the data is the presence of a slightly enhanced signal in the Cooper Creek downstream of the minesite, close to the north-east corner of the flight area. Enhanced eU, ${ }^{40} \mathrm{~K}$ and particularly eTh signals are also present along the nearby tributary to the Cooper Creek. Hence the Cooper Creek signal here is probably not (or at most only partly) mine-related. At count rates $5-10 \%$ of the maximum (and hence not evident in Figure 3), signals are present downstream of the mine and around the confluence with Buffalo Creek, where any runoff from the Nabarlek mine would be likely to occur. However, a signal is also present upstream of the confluence. Furthermore, elevated signals were also indicated along the Cooper Creek line in the premining data of the original environmental impact statement (QML, 1979).

The Cooper Creek main channels have a bed consisting primarily of clean, unconsolidated quartz sand. Finer material is deposited on the banks and islands, and in shallow depressions to the sides of the main flow channels. Although the channel beds have low activity concentrations of ${ }^{40} \mathrm{~K}$, eU and eTh, they comprise a relatively small area compared with the banks and islands, which contain the 
higher-activity fine sediments. The large footprint of the airborne survey gives an average creek-region eU signal, however it is noteworthy that the magnitude of the signal is of sufficient size to distinguish the creek from surrounding (woodland) areas. These findings are consistent with the results of previous ground-based studies of radionuclide transport and deposition in the Magela Creek, a similarly sandy braided channel creek about $60 \mathrm{~km}$ south-west of Nabarlek (Murray et al., 1992; Wasson, 1992).

To the south-west of the Nabarlek site is an area with relatively high ${ }^{40} \mathrm{~K}$ and eTh count rates, but only a slightly elevated mean eU count rate. These features are correlated with rocky outcrops of the Myra Falls Metamorphics which contain significant amounts of potassium in their structures. Some evidence of this can be seen from the Bureau of Mineral Resource Data geochemical characteristics of rocks in the Nabarlek area, samples 79080034 to 79472411 inclusive (Wyborn and Ryburn, 1991). These samples ranged in $\mathrm{K}_{2} \mathrm{O}$ concentration from $0.04 \%$ to $8.49 \%$.

\section{Comparison with Ground-Based Measurements}

Comparisons between airborne and ground-based readings should be treated with caution, since the "footprints" of the two techniques are quite different. Portable $\mathrm{NaI}(\mathrm{Tl})$ and GM tube measurements were made at $1 \mathrm{~m}$ height at fixed locations. Assuming a plane ground source with homogeneous activity concentrations, then approximately $56 \%$ of the signal will come from a circle of $2 \mathrm{~m}$ radius around the location, while approximately $92 \%$ will come from within a $10 \mathrm{~m}$ radius (IAEA, 1989). Hence the measurement is quite localised.

By contrast, the aircraft flew an average distance of $60 \mathrm{~m}$ during one measurement period, and the nominal spacing between flight lines was $100 \mathrm{~m}$. Hence it is unrealistic to expect a better spatial resolution than $100 \times 60 \mathrm{~m}$. Further, at a height of $50 \mathrm{~m}$ about $60 \%$ of the signal will come from outside a circle of radius $50 \mathrm{~m}$ (again assuming a plane, isotropic ground source; Duval et al., 1971). This means that a significant fraction of the (pre-gridded) signal will be from outside the nominal $100 \times 60 \mathrm{~m}$ measurement strip.

Another difference between the two techniques is that the counting period for the ground-based measurements may be varied, allowing longer count times and hence improved statistics for low-activity regions, whereas it is fixed for the airborne method. For the Nabarlek flight, the above-background peak count rate was commonly 10 to 30 counts s ${ }^{-1}$ over relatively low-activity regions (see Figures $3-$ 5 ), and so for these areas large fluctuations in the peak count rate arising from counting statistic variations can be expected, especially for the eTh count rate.

Detailed results are presented below for three of the transects performed: those over the LAA/EP1/SPROP, EP2, and staff accommodation areas. The selected transects are representative of the general relationship between the ground and air measurements and also show several features of interest. The first two of these 
transects include regions of high count rate, and so statistical counting uncertainties are relatively small in these cases.

\subsection{LAA/EP1/SPROP TRANSECT}

Figure 6 shows results from a transect across the airstrip and former land application (LAA), evaporation pond 1 (EP1) and stockpile runoff pond (SPROP) areas. The broad features of the airborne and ground-based data agree reasonably well, e.g. higher ${ }^{40} \mathrm{~K}$, eU and eTh signals above the former pond areas, with peak eU signal above EP1, peak ${ }^{40} \mathrm{~K}$ above the south-west end of the SPROP and increased eTh to the south-west of the airstrip as well as over the ponds.

The airborne data show less fine detail than the ground-based data, as expected from their larger footprint. As a result, peaks and troughs in the ground-based signal can be missed in the airborne signal. In Figure 6 this is most obvious for the eU and ${ }^{40} \mathrm{~K}$ results. Another example can be seen in the ${ }^{40} \mathrm{~K} / \mathrm{eU}$ ratio data between the south-west of the airstrip and the start of the former EP1 area. Over this $\sim 250 \mathrm{~m}$ section the ground-based data show alternating low-high-low-high ratios, whereas the airborne data are relatively constant. The low ratios observed for the groundbased data over the LAA can reasonably be attributed to the low ${ }^{40} \mathrm{~K} /{ }^{26}$ Ra ratio in the water spray irrigated over this area. Similarly low ${ }^{40} \mathrm{~K} / \mathrm{eU}$ values were observed for ground-based data over the forest LAA, and at the north-east end of the ore stockpile transect over the former location of the mill-SPROP water pipeline.

Another feature of Figure 6 is that the ratio of readings from high-activity areas to those from low-activity areas is lower for the airborne than for the ground-based data. For example, the ratio of the mean eU signal for the former EP1 area to that for the area south-west of the airstrip is $\sim 3.1$ for the ground-based data but only $\sim 2.4$ for the airborne data. This difference is most probably a consequence of the different footprint of the two techniques, as discussed above. For this transect, the main area of elevated ${ }^{40} \mathrm{~K}$ and eU activity is that above the EP1 and SPROP areas, a distance of $\sim 400 \mathrm{~m}$. The ground-based data show that the ${ }^{40} \mathrm{~K}$ and eU activity concentrations fall off rapidly beyond the ends of this part of the transect. The airborne data show a much more gradual decline. Again, the effect of the relative footprint sizes will contribute to this difference. An additional contribution could also arise if the gridding software does not adequately account for the portion of the signal which arises from outside of the nominal $100 \times 60 \mathrm{~m}$ measurement area.

\subsection{EP2 TRANSECT}

Figure 7 shows the results of a transect across the location of the former evaporation pond 2 (EP2) area. As for the LAA/EP1/SPROP transect, the airborne technique does not show the variability in signal apparent from the ground-based data, but the broad features of the two datasets are similar and the agreement between the datasets is good. 

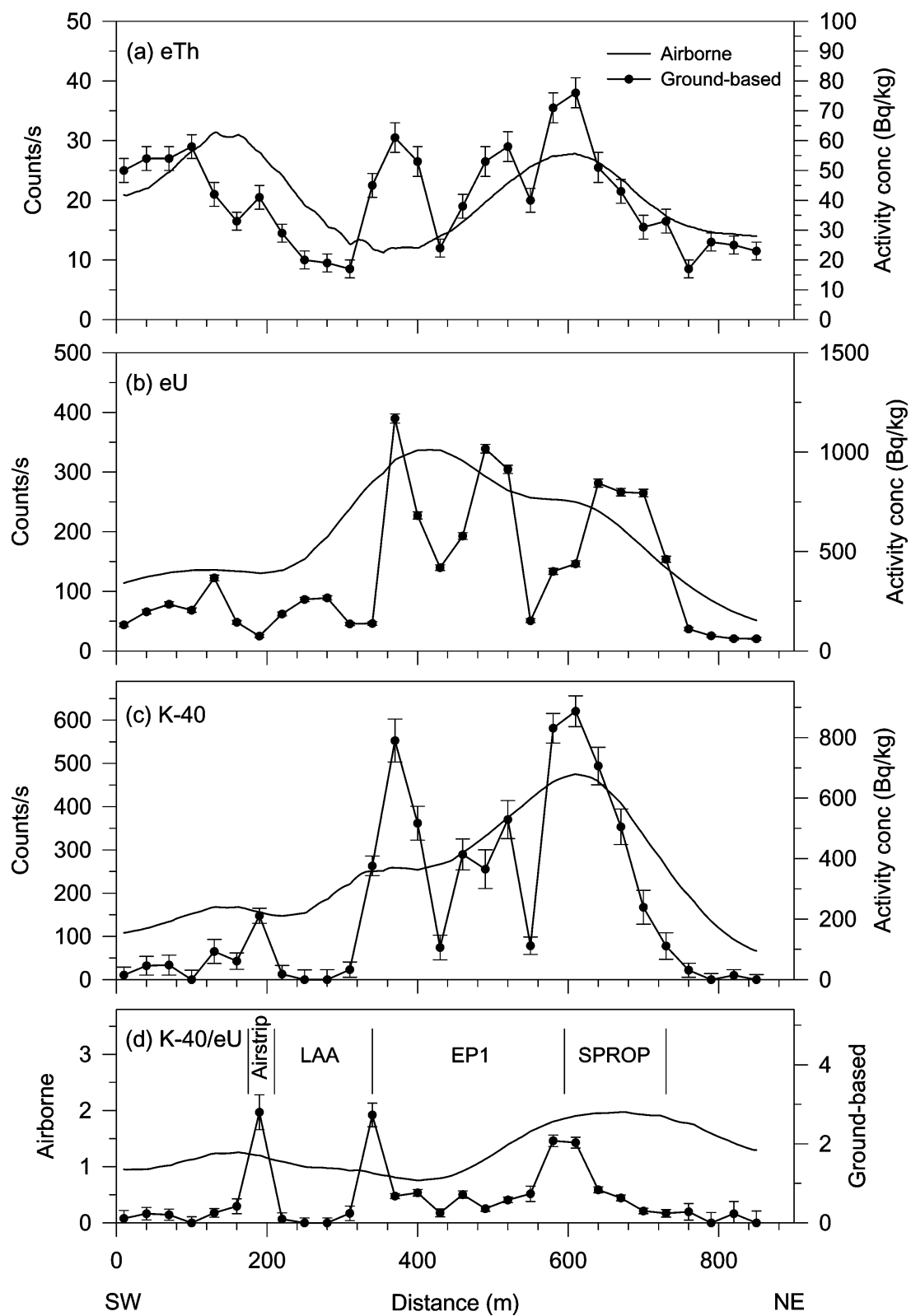

Figure 6. Transect across the airstrip and the former LAA, EP1 and SPROP areas. (a) eTh, (b) eU, (c) ${ }^{40} \mathrm{~K}$ and (d) ${ }^{40} \mathrm{~K} / \mathrm{eU}$ data and locations of features. Error bars represent counting statistics alone, and correspond to one standard deviation.

An interesting feature of the airborne data, which is confirmed by the groundbased transect, is apparent in the area around the south-west corner of EP2. The average ${ }^{40} \mathrm{~K}$ and eTh count rates in this corner area are of similar magnitude to the rest of the EP2 region, while those for $\mathrm{eU}$ are somewhat reduced relative to 

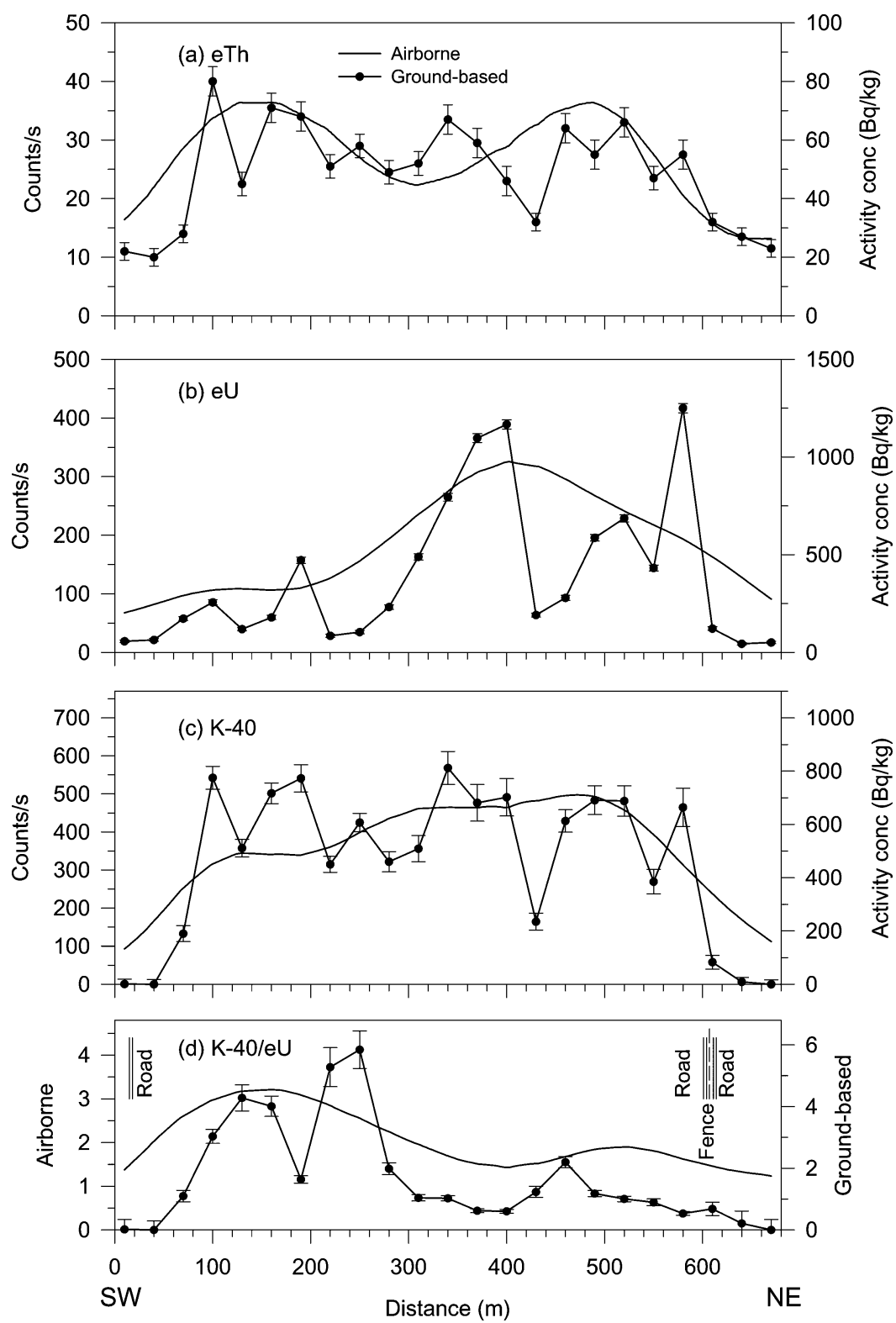

Figure 7. Transect across the former EP2 area. (a) eTh, (b) eU, (c) ${ }^{40} \mathrm{~K}$ and (d) ${ }^{40} \mathrm{~K} / \mathrm{eU}$ data and locations of features. Error bars represent counting statistics alone, and correspond to one standard deviation.

the rest of the transect. This reduction is reflected in Figure $7 \mathrm{~d}$ which shows the ${ }^{40} \mathrm{~K} / \mathrm{eU}$ ratio to be higher in this region than over other evaporation pond areas. The area is not known to have received a different treatment on rehabilitation from the surrounding areas, and the reason for the high ratio remains unclear. 


\subsection{STAFF ACCOMODATION AREA TRANSECT}

Figure 8 shows the results for a north-south transect across the former staff accommodation area. This area is quite inhomogeneous, with roads and tracks, the remains of buildings and machinery, and rocky sandstone outcrops. The transect crossed a concreted area (the former open-air cinema); the ground-based data show elevated signals for ${ }^{40} \mathrm{~K}$, eU and eTh, as well as a high ${ }^{40} \mathrm{~K} / \mathrm{eU}$ ratio, above this area. To the south of this, high readings for eU were obtained over the former vehicle

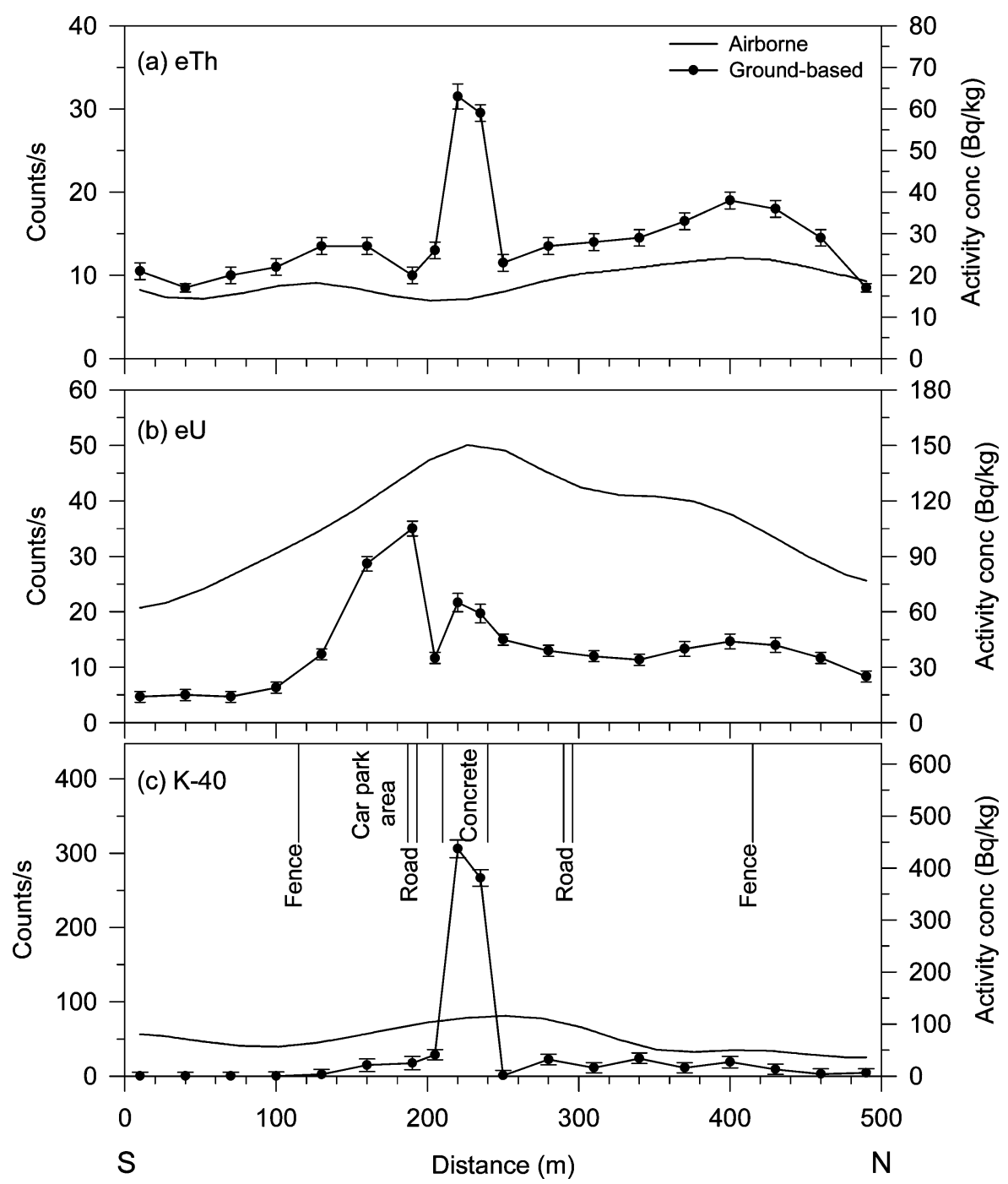

Figure 8. Transect across the former staff accommodation area. (a) eTh, (b) eU, (c) ${ }^{40} \mathrm{~K}$ and locations of features. Error bars represent counting statistics alone, and correspond to one standard deviation. 
parking area (Figure 8b). These detailed features are not seen in the airborne data, but this is not surprising given the inhomogeneous nature of the area and the different footprints of the two techniques. Both datasets show higher ${ }^{40} \mathrm{~K}$ and eU readings within the fenced area than outside the fence.

\section{6. $\gamma$ Dose Rate Estimation}

The results discussed above show that the airborne technique is useful in obtaining an at least semi-quantitative "picture" of the location and extent of radioactive contamination at a uranium minesite. The correlations observed between groundbased and airborne measurements imply that this may be extended to using the airborne count rates as quantitative measures of activity concentrations in the soil and $\gamma$ dose rates at $1 \mathrm{~m}$ height. If this were shown to be so, then the technique could be extremely useful for obtaining such estimates over large areas, although as shown above there are limitations on the spatial resolution of the method. Such a possibility would be of interest to managers and regulators of minesites, particularly when assessing the adequacy of rehabilitation from a radiological perspective.

Figure 9 shows ground-based eTh, eU and ${ }^{40} \mathrm{~K} \mathrm{NaI}(\mathrm{Tl})$ measurements from the transects plotted against the corresponding airborne data. As discussed above, the best spatial resolution which could be expected from the airborne data was 60 to $100 \mathrm{~m}$. Consequently, for the present purposes the data were combined along lengths of the transects of a similar order of magnitude to this (mean of 3 groundbased data points where these were $30 \mathrm{~m}$ apart, or of 6 data points where these were $15 \mathrm{~m}$ apart). The error bars in Figure 9 show the standard deviations of the ground-based measurements.

For all three cases, there is a positive correlation between airborne and groundbased data. In the following, we attempt to derive a method for prediction of radionuclide activity concentrations in the ground (and subsequently predict absorbed dose rate from gamma radiation near ground level) from the airborne data. Figure 9 shows straight-line fits to the data:

$$
G=m A
$$

where $G$ is the ground-based $\mathrm{NaI}(\mathrm{Tl})$ reading $\left(\mathrm{Bq} \mathrm{kg}^{-1}\right), A$ is the airborne signal (counts $\mathrm{s}^{-1}$ ) and $m$ is the gradient of the fitted line $\left(\mathrm{Bq} \mathrm{kg}^{-1}\right.$ per counts $\mathrm{s}^{-1}$ ). Table II lists the results obtained from a least-squares fit through the data.

The terrestrial component of the absorbed dose rate ${ }^{1}, D$, which is attributable to $\gamma$ rays from ${ }^{40} \mathrm{~K}$, eU and eTh activity may be approximated by the following function:

$$
D=a_{1} \mathrm{~K}+a_{2} \mathrm{eU}+a_{3} \mathrm{eTh}
$$

where $\mathrm{K}, \mathrm{eU}$ and eTh represent activity concentrations in the ground $\left(\mathrm{Bq} \mathrm{kg}^{-1}\right)$, and $a_{i}$ are the appropriate dose rate coefficients. UNSCEAR (2000, Table VI of 

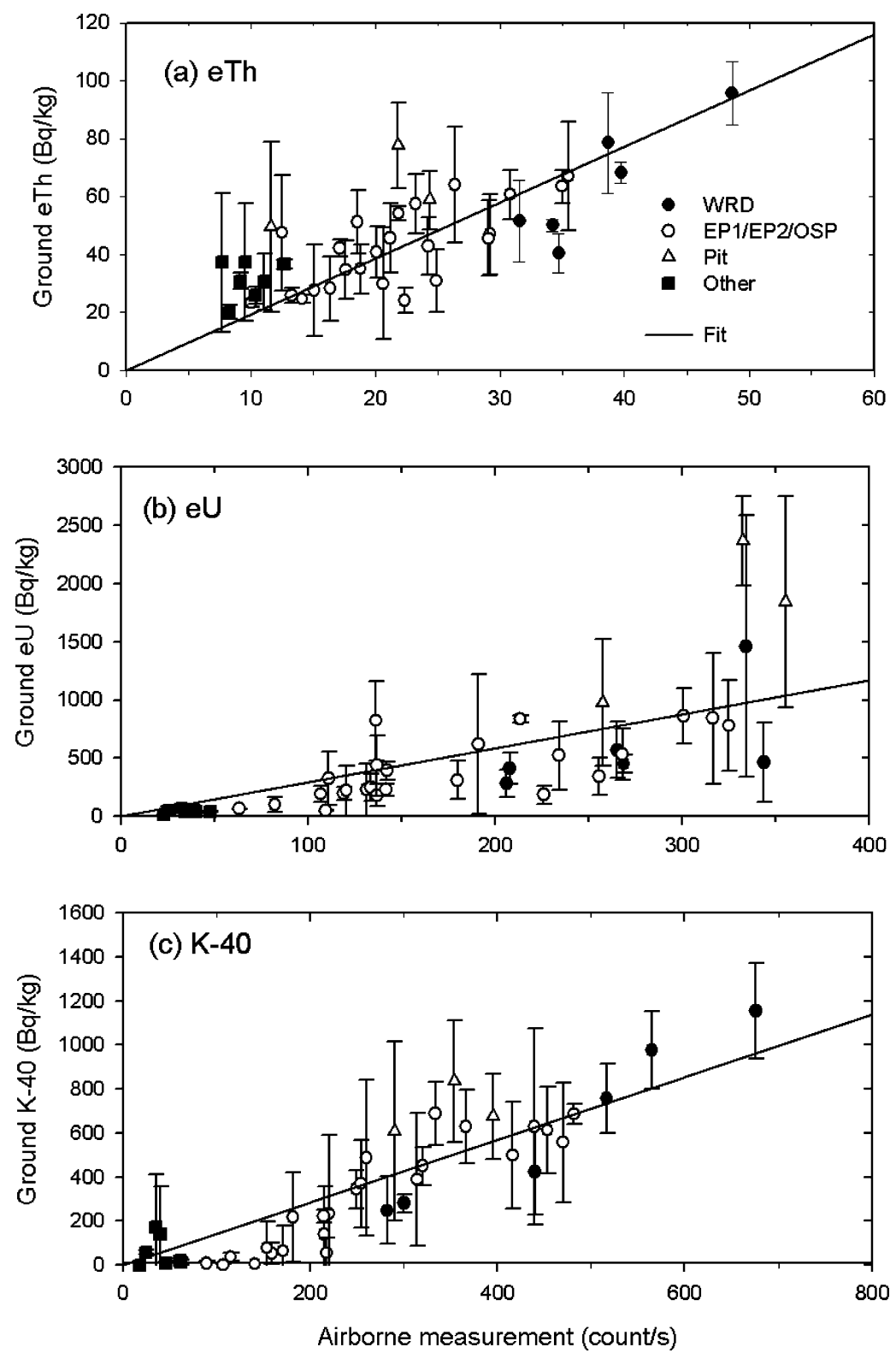

Figure 9. Airborne vs. ground-based measurements for (a) eTh, (b) eU and (c) ${ }^{40} \mathrm{~K}$. Error bars show one standard deviation for the averaged ground-based measurements.

Annex B) quote average values ${ }^{2}$ for $a_{1}, a_{2}$ and $a_{3}$ of $0.0417,0.462$ and $0.604 \mathrm{nGy}$ $\mathrm{hr}^{-1}$ per Bq kg ${ }^{-1}$, respectively.

By extracting the airborne count rate data for ${ }^{40} \mathrm{~K}, \mathrm{eU}$ and $\mathrm{eTh}$ for each pixel over any area of interest, applying Equations (1) and (2) to obtain $D$ for each of these pixels, and then averaging these values we can obtain an estimate of the 
TABLE II

Derived parameter values for $m\left(\mathrm{~Bq} \mathrm{~kg}^{-1}\right.$ per counts s$\left.{ }^{-1}\right)$ for Equation (1)

\begin{tabular}{lccc}
\hline & ${ }^{40} \mathrm{~K}$ & $\mathrm{eU}$ & $\mathrm{eTh}$ \\
\hline$m$ & 1.43 & 2.92 & 1.93 \\
$R^{2}$ & 0.80 & 0.53 & 0.41 \\
\hline$n=40$. & & &
\end{tabular}

TABLE III

Estimates of post-mining terrestrial-origin $\gamma$ dose rate, $D$, for areas of the Nabarlek site

\begin{tabular}{lcl}
\hline Site & Area (ha) & $D\left(\mu \mathrm{Gy} \mathrm{hr}^{-1}\right)$ \\
\hline Pit & 4 & 0.51 \\
Evaporation pond 1 (EP1) & 6 & 0.48 \\
Waste rock runoff pond & 1.9 & 0.47 \\
Waste rock dump (WRD) & 8 & 0.46 \\
Evaporation pond 2 (EP2) & 25 & 0.37 \\
Plant runoff pond & 1.1 & 0.36 \\
Stockpile runoff pond (SPROP) & 4 & 0.36 \\
Ore stockpile (OSP) & 6 & 0.24 \\
Plant and offices & 6 & 0.18 \\
Airstrip LAA & 10 & 0.09 \\
Forest LAA & 13 & 0.05 \\
Total fenced area & 140 & 0.31 \\
\hline
\end{tabular}

average terrestrial-origin $\gamma$ absorbed dose rate over any area of interest. Estimates for the major areas on the Nabarlek site are given in Table III. With the exception of the forest land application area, the dominant contribution to $D$ was from eU, as expected. For example, for the pit area the percentage contributions from ${ }^{40} \mathrm{~K}$, eU and eTh were $4 \%, 92 \%$ and $4 \%$ respectively; for the total fenced area they were $5 \%, 85 \%$ and $10 \%$, respectively.

As discussed above, ground-based readings were made at randomized locations over the former plant/offices and plant runoff pond areas. As these data were not used in the derivation of the parameters for Equation (1) above, they will be used here as an independent check on the reliability of use of these parameters for estimating gamma dose rates on the ground. For the plant/offices area, measurements were made using both a $\mathrm{NaI}(\mathrm{Tl})$ detector and a $\mathrm{GM}$ tube at the same locations. The GM tube measurements include a contribution from cosmic radiation, which has been estimated to be $0.07 \mu \mathrm{Gy} \mathrm{hr}^{-1}$ for the region (Marten, 1992), and which must be subtracted to compare with the $\mathrm{NaI}(\mathrm{Tl})$ readings; the mean $\mathrm{GM}$ tube readings quoted below have had this figure subtracted to allow the comparison. 
For the plant/offices area, the resultant estimate of $D$ obtained was $0.13 \mu \mathrm{Gy}$ $\mathrm{hr}^{-1}(\sigma=0.09 ; n=24)$ from the NaI(Tl) detector and $0.11 \mu \mathrm{Gy} \mathrm{hr}{ }^{-1}(\sigma=$ $0.06 ; n=24)$ from the GM tube measurements. These estimates compare with the estimate of $0.18 \mu \mathrm{Gy} \mathrm{hr}^{-1}$ from the airborne gamma data (Table III). Readings over the plant runoff pond were made only with the GM tube, and gave a mean of $0.38 \mu \mathrm{Gy} \mathrm{hr}^{-1}(\sigma=0.08 ; n=13)$, compared with the estimate of $0.36 \mu \mathrm{Gy}$ $\mathrm{hr}^{-1}$ from the airborne gamma data (Table III). For radiological impact assessment purposes, variations in dose rate estimates between independent techniques of the order of those observed here would be considered adequate, as other factors (such as estimates of occupancy) are likely to introduce far greater uncertainties on the final dose rate assessment.

At present, the overall framework used by radiological protection regulators in Australia is based on NHMRC (1995). This document is in turn based in large part upon recommendations in ICRP (1991). Under this framework, dose limits applying to practices such as uranium mining operations refer only to the excess dose above background. The public dose limitation is that of an annual effective dose of $1 \mathrm{mSv}$ in a year above background. Therefore, to assess the suitability of the site for future use, an estimate of the pre-mining dose rate is required.

The original environmental impact statement for the Nabarlek project (QML, 1979) contained a pre-mining dose rate contour diagram of the orebody region; values shown range from $0.5 \mu \mathrm{Gy} \mathrm{hr}^{-1}$ to greater than $4 \mu \mathrm{Gy} \mathrm{hr}{ }^{-1}$. Integrating over the diagram gives an average absorbed dose rate of $1.6 \mu \mathrm{Gy} \mathrm{hr}^{-1}$ over an area of 4 hectares. This figure is higher than the post-mining dose rate obtained in this study $\left(0.51 \mu \mathrm{Gy} \mathrm{hr}^{-1}\right)$, but this is reasonable as the mining operation removed ore outcropping at the surface.

Unfortunately, a similar pre-mining dataset for the remainder of the site is not available. Consequently, we will use here an estimated terrestrial-origin $\gamma$ absorbed dose rate of $0.04 \mu \mathrm{Gy} \mathrm{hr}^{-1}$, based upon the soil activity concentrations obtained from a transect across the soil stockpile area (Figure 2). Hence the area-weighted average pre-mining figure for the total fenced area is $0.08 \mu \mathrm{Gy} \mathrm{hr}^{-1}$, and the derived increase attributed to the mining operation is $(0.31-0.08)=0.23 \mu \mathrm{Gy} \mathrm{hr}^{-1}$.

Use of such an area-averaged figure would be adequate in an assessment of hunting and camping activities. If we assume a conservative (i.e. high) rate of occupancy for these activities of 30 days per year, and a conversion factor from measured absorbed dose to effective dose of $0.79 \mathrm{~Sv} \mathrm{~Gy}^{-1}$ for a child (UNSCEAR, 2000, Table VIII of Annex A), the resultant above-premining effective dose rate (from $\gamma$ radiation alone) is $0.13 \mathrm{mSv} \mathrm{yr}^{-1}$.

If other occupancy scenarios were to eventuate, other factors could come into play. An example would be a scenario in which a dwelling is built on the site. In this case, the use of an area-averaged figure would be less defensible, because occupancy would be concentrated primarily in a relatively small area. Nevertheless, the survey data would be expected to provide useful information on which general areas are more, or less, likely to be suitable for such a purpose. 
For a full dose estimate under any occupancy scenario, other pathways such as inhalation of radon progeny and dust, ingestion of foods, water and soil, erosion of soils from the site etc. will need to be taken into account, and work is underway to investigate these (e.g. Bollhöfer et al., 2003, 2004). Nevertheless, the present work does enable estimates of the contribution to dose rates from $\gamma$ radiation to be made. In addition, it is proving invaluable in designing the project work for the studies of other dose pathways.

If the soil stockpiles had been used to cover the disturbed areas, then $\gamma$ dose rates would have been reduced. Table III shows that at Nabarlek the highest dose rates are obtained for relatively small areas such as the former pit, evaporation pond 1, waste rock dump and waste rock dump runoff pond areas. Use of topsoil would also have had a favourable effect on other dose pathways. This suggests a further application of airborne $\gamma$ surveys: the targeting of areas for soil cover during minesite rehabilitation.

\section{Conclusions}

This study demonstrates that airborne $\gamma$-radiometric surveys are a potentially useful tool for radiological impact assessment of uranium mining operations. Spatial resolution can be on the order of the flight line spacing, depending on the signal strength and juxtaposition of nearby signals. This can be sufficient to distinguish man-made structures (such as ponds and accommodation areas) and fluvial processes. However, in order to realise the potential of the technique it is essential that surveys be carried out with smaller flight line spacings and lower aircraft heights than has been the practice for exploration applications. It is also advantageous to only allow data collection to commence after the early morning period of elevated ${ }^{222} \mathrm{Rn}$ concentrations in air has passed, in order to avoid striping in the eU dataset.

With proper calibration, the technique should be able to give reasonable areaaveraged estimates of activity concentrations of $\mathrm{K}$, eU and eTh in surface soils, and consequently allow a deduction of the $\gamma$ dose rate. However, the spatial resolution must be kept in consideration whenever estimates of actual doses received by humans are required, and it is recommended that ground-level measurements be carried out in conjunction with the airborne survey in such cases. Nevertheless, the airborne survey method is invaluable in helping to plan such ground-level investigations.

This study also highlights the need for collection of pre-mining data for estimation of the dose increase which can result from a mining operation. Airborne gamma data are well suited for such a purpose. Also of use would be collection of data during the mining phase, because this can highlight areas where attention can be focussed during the rehabilitation process. Such data also would assist in assessment of the success of rehabilitation on its completion. 
It should be noted that the airborne/ground relation discussed in this paper (i.e. Equation (1) and derived parameters) has been developed solely for the present Nabarlek datasets, and would not be appropriate for use without modification on other datasets.

\section{Acknowledgments}

The airborne $\gamma$ survey of Nabarlek was jointly funded by the Environmental Research Institute of the Supervising Scientist and the Northern Territory Department of Business, Industry \& Resource Development. The authors would also like to thank Bernard Prendergast for helping initiate this project, Thérèse Fox, Eric Rennex and Phillip Mabbott for assistance with the fieldwork, Peter Bailey for discussions on the history of mining and rehabilitation at Nabarlek, and Roger Clifton, Sergey Fesenko, Arthur Johnston and Alex Zapantis for useful discussions. The contribution of one of the authors (PM) was part of his studies in the $\mathrm{PhD}$ program at the Queensland University of Technology.

\section{Notes}

1. The absorbed dose is the energy absorbed per unit mass. Its unit is the joule per kilogram, named the gray $(\mathrm{Gy})$. In order to relate an absorbed dose to its potential for causing a stochastic radiation effect in a human, it is converted to an effective dose by the use of weighting factors according to the type of radiation and the type of tissue irradiated. The unit of effective dose is the sievert (Sv). See ICRP (1991).

2. The UNSCEAR (2000) coefficients represent approximate values. The true dose rate coefficients will depend on site-specific factors such as soil moisture, the elemental composition of the soil, activity concentration variability with depth, the presence of decay chain disequilibrium, etc. These were considered to be minor sources of uncertainty in the final dose estimates in comparison with other assumptions, in particular those for occupancy rates.

\section{References}

Anthony, P. J.: 1975, 'Nabarlek Uranium Deposit', in: C. L. Knight (ed), Economic Geology of Australia and Papua New Guinea. 1 Metals. Australian Institute of Mining and Metallurgy Monograph No 5, pp 304-407.

Battey, G. C., Mietzitis, Y. and McKay, A. D.: 1987, ‘Australian Uranium Resources', Bureau of Mineral resources, Geology and Geophysics, Resource Report 1, Australian Government Publishing Service, Canberra.

Bollhöfer, A., Storm, J., Martin, P. and Tims, S.: 2003, 'Geographic Variability in Radon Exhalation at the Rehabilitated Nabarlek Uranium Mine, Northern Territory’, Internal Report 465, Supervising Scientist, Darwin. Unpublished paper.

Bollhöfer, A., Martin, P., Tims, S. and Ryan, B.: 2004, 'High Sensitivity Airborne Radon Concentration Measurements in the Alligator River Region: Rehabilitated Nabarlek Uranium Mine', Internal Report 469, Supervising Scientist, Darwin. Unpublished paper. 
Clifton, R. L.: 1989, 'Processing Methods for Multichannel Radiometric Data with Application to Atmospheric Radon', M.App.Sc. Thesis, Curtin University of Technology, Perth.

Cook, S. E., Corner, R. J., Groves, P. R. and Grealish, G. J.: 1996, 'Use of airborne gamma radiometric data for soil mapping', Australian J. Soil Res. 34, 183-194.

Dickson, B. L. and Scott, K. M.: 1997, 'Interpretation of aerial gamma-ray surveys - adding the geochemical factors', AGSO J. Australian Geol. Geophys. 17, 187-200.

Duval, J. S., Cook, B. and Adams, J. A. S.: 1971, 'Circle of investigation of an air-borne gamma-ray spectrometer', J. Geophys. Res. 76, 8466-8470.

Galbraith, J. H. and Saunders, D. F.: 1983, 'Rock classification by characteristics of aerial gamma-ray measurements', J. Geochem. Exploration 18, 49-73.

IAEA: 1989, 'Construction and Use of Calibration Facilities for Radiometric Field Equipment', Technical Reports Series No. 309, IAEA, Vienna.

IAEA: 1991, 'Airborne Gamma Ray Spectrometer Surveying', Technical Reports Series No. 323, IAEA, Vienna.

ICRP: 1991, 1990 Recommendations of the International Commission on Radiological Protection, Publication 60 of the ICRP, Pergamon Press, Oxford.

Kleinschmidt, R.: 1998, 'The Investigation, Assessment, Remediation and Management of a Tin Mineral Processing Site Contaminated with Technologically Enhanced Concentrations of Naturally Occurring Uranium and Thorium', in: R.A. Akber \& P. Martin (eds), Radiological Aspects of the Rehabilitation of Contaminated Sites, pp. 15-28, South Pacific Environmental Radioactivity Association, Christchurch.

Lepel, E. A., Geelhood, B. D., Hensley, W. K. and Quam, W. M.: 1998, 'A field-deployable, aircraftmounted sensor for the environmental survey of radionuclides', J. Radioanal. Nuclear Chem. Articles 233, 211-215.

Marten, R.: 1992, 'External Gamma Dose Rate Survey of the Ranger Land Application Plot', in: Proceedings of the Workshop on Land Application of Effluent Water from Uranium Mines in the Alligator Rivers Region, Jabiru, 11-13 September 1991. Supervising Scientist for the Alligator Rivers Region, AGPS, Canberra.

Martin, P., Tims, S., Ryan, B. and Bollhöfer, A.: 2004, 'A radon and meteorological measurement network for the Alligator Rivers Region, Australia', J. Environ. Radioactivity 76, 35-49.

Minty, B. R. S., Luyendyk, A. P. J. and Brodie, R. C.: 1997, 'Calibration and data processing for airborne gamma-ray spectrometry', AGSO J. Australian Geol. Geophys. 17, 51-62.

Murray, A. S., Johnston, A., Martin, P., Hancock, G., Marten, R. and Pfitzner, J.: 1992, 'Transport of Naturally Occurring Radionuclides in the Surface Waters of Magela Creek and Flood Plain, Northern Australia', Open File Record 93, Supervising Scientist for the Alligator Rivers Region, Canberra.

Needham, R. S.: 1988, 'Geology of the Alligator Rivers Uranium Field', Northern Territory Bureau of Mineral Resources, Geology and Geophysics Bulletin No 224, AGPS, Canberra.

Needham, R. S. and Stuart-Smith, P. G.: 1976, 'The Cahill Formation - Host to Uranium Deposits in the Alligator Rivers Uranium Field, Australia', J. Australian Geol. Geophys. I, 321333

NHMRC: 1995, 'Recommendations for Limiting Exposure to Ionizing Radiation (Guidance Note [NOHSC:3022(1995)]) and National Standard for Limiting Occupational Exposure to Ionizing Radiation [NOHSC:1013(1995)]', Radiation Health Series No. 39, June 1995. National Health and Medical Research Council, AGPS, Canberra.

Pickup, G. and Marks, A.: 2000, 'Identifying large-scale erosion and deposition processes from airborne gamma radiometrics and digital elevation models in a weathered landscape', Earth Surface Processes Landforms 25, 535-557.

Plant, J. A. and Saunders, A. D.: 1996, 'The radioactive Earth', Radiation Protect. Dosimetry 68, $25-36$. 
Queensland Mines Limited (QML): 1979, 'Final Environmental Impact Statement: Nabarlek Uranium Mine Project, Arnhem Land, Northern Territory', January 1979, Queensland Mines Limited.

Smith, R. J.: 1985, 'Geophysics in Australian mineral exploration', Geophysics 50, 2637-2665.

UNSCEAR: 2000, 'Sources and Effects of Ionizing Radiation. Volume 1: Sources', United Nations Scientific Committee on the Effects of Atomic Radiation UNSCEAR 2000, Report to the General, Assembly, United Nations, New York.

Uren, C.: 1992, 'An Investigation of Surface Geology in the Alligator Rivers Region for Possible Analogues of Uranium Mine Rehabilitation Structures', Internal Report 56, Supervising Scientist for the Alligator Rivers Region, Darwin. Unpublished Paper.

Waggitt, P. W. and Woods, P. H.: 1998, 'Nabarlek Uranium Mine, Northern Australia: History, Rehabilitation and Groundwater Studies', in: B. Merkel \& C. Helling (eds.), Uranium Mining and Hydrogeology, pp. 603-612.

Waggitt, P.: 2001, 'The Decommissioning and Rehabilitation of the Nabarlek Uranium Mine, northern Australia', in: D.A. Klessa (ed), The Rehabilitation of Nabarlek Uranium Mine: Proceedings of Workshop, Darwin NT, Australia, 18-19 April 2000. Supervising Scientist Report 160, Supervising Scientist, Darwin, pp 16-25.

Wasson, R. J. (ed): 1992, 'Modern Sedimentation and Late Quaternary Evolution of the Magela Creek Plain', Research Report 6, Supervising Scientist for the Alligator Rivers Region, AGPS, Canberra.

Wilford, J. R., Bierwirth, P. N. and Craig, M. A.: 1997, 'Application of airborne gamma-ray spectrometry in soil/regolith mapping and applied geomorphology', AGSO J. Australian Geol. Geophys. 17, 201-216.

Winkelmann, I., Thomas, M. and Vogl, K.: 2001, 'Aerial measurements on uranium ore mining, milling and processing areas in Germany', J. Environ. Radioactivity 53, 301-311.

Wyborn, L. A. I. and Ryburn, R. J.: 1991, 'Pine Creek Rockchem Data Set Documentation', Record 1991/40, Bureau of Mineral Resources, Geology and Geophysics, Canberra, Australia.

Zhang, Y., Xiong, S. and Chen, T.: 1998, 'Application of airborne gamma-ray spectrometry to geoscience in China', Appl. Radiation Isotopes 49, 139-146. 